\title{
Acclimatization of Tapeinochilos ananassae plantlets in association with arbuscular mycorrhizal fungi
}

\author{
João Ricardo Gonçalves de Oliveira(1), Thiago Alberto de Lima Morais(2), Natoniel Franklin de Melo(3) \\ and Adriana Mayumi Yano-Melo(4)
}

\begin{abstract}
(1) Universidade Federal de Pernambuco, Centro de Ciências Biológicas, Departamento de Micologia, Rua Nelson Chaves, s/no, CEP 50670-420 Recife, PE, Brazil. E-mail: jrgoliveira@yahoo.com.br (2)Companhia Vale do Rio Doce, Avenida Vicinal Picadão, Km 22, CEP 68390-000 Ourilândia do Norte, PA, Brazil. E-mail: thiago.morais@vale.com ${ }^{(3)}$ Embrapa Semiárido, Caixa Postal 23, CEP 56304-970 Petrolina, PE, Brazil. E-mail: natoniel@cpatsa.embrapa.br ${ }^{(4)}$ Universidade Federal do Vale do São Francisco, Avenida José de Sá Maniçoba, s/no, Centro, CEP 56304-917 Petrolina, PE, Brazil. E-mail: amymelo17@hotmail.com
\end{abstract}

\begin{abstract}
The objective of this work was to assess the potential of three isolates of arbuscular mycorrhizal fungi to promote growth of micropropagated plantlets of Tapeinochilos ananassae during acclimatization. The experiment was carried out in greenhouse, in a completely randomized block design, with four inoculation treatments: non-inoculated control and plants inoculated with Glomus etunicatum, Acaulospora longula or Gigaspora albida, with ten replicates. After 90 days, the following parameters were evaluated: survival rate, height, leaf and tiller number, leaf area, fresh and dry biomass, contents of macro- and micronutrients in the root and shoot, glomerospore number, and mycorrhizal colonization. The survival percentage was $100 \%$, except for plants inoculated with G. albida (80\%). The isolate G. etunicatum is more suitable for plant development, since it improves survival, growth, dry matter production, nutritional status, and vigor of $T$. ananassae micropropagated plants.
\end{abstract}

Index terms: Glomeromycota, growth promotion, micropropagation, mineral nutrition, tropical flowers.

\section{Aclimatização de plântulas de Tapeinochilos ananassae em associação com fungos micorrízicos arbusculares}

\begin{abstract}
Resumo - O objetivo deste trabalho foi avaliar o potencial de três isolados de fungos micorrízicos arbusculares na promoção do crescimento de plântulas micropropagadas de Tapeinochilos ananassae durante a fase de aclimatização. O experimento foi realizado em casa de vegetação, tendo-se utilizado o delineamento inteiramente casualizado, com quatro tratamentos de inoculação: controle não inoculado e plantas inoculadas com Glomus etunicatum, Acaulospora longula ou Gigaspora albida, com dez repetições. Após 90 dias, foram avaliados os seguintes parâmetros: percentual de sobrevivência, altura, número de folhas e de perfilhos, área foliar, biomassa fresca e seca, conteúdo de macro e micronutrientes nas partes aérea e radicular, número de glomerosporos e colonização micorrízica. O percentual de sobrevivência foi de $100 \%$, exceto para as plantas inoculadas com G. albida (80\%). O isolado G. etunicatum é o mais adequado para o desenvolvimento das plantas, pois aumenta a sobrevivência, o crescimento, a produção de matéria seca, o conteúdo nutricional e o vigor de plantas micropropagadas de T. ananassae.
\end{abstract}

Termos para indexação: Glomeromycota, promoção do crescimento, micropropagação, nutrição mineral, flores tropicais.

\section{Introduction}

The great diversity of climates and soils in Brazil allow the cultivation of numerous species of ornamental plants and flowers, with potential to compete in the international market (Cançado Júnior et al., 2005). Among the tropical ornamental plants, the genus Tapeinochilos comprises 16 species, of which $80 \%$ are endemic to the island of New Guinea, and is characterized by the formation of inflorescences composed of bright red bracts of great beauty and post-harvest durability (Specht \& Stevenson, 2006). Tapeinochilos ananassae (Hassk.) K. Shum. is still poorly known in Brazil, but has excellent prospects for acceptance by cultivators and consumers.

Commercial production of ornamental plants has evolved greatly to become an extremely competitive activity, but it requires technology, advanced knowledge, and efficient marketing (Pasqual et al., 2008). Consequently, vegetative, in vitro propagation (micropropagation) has been widely applied to produce, in a short time and at any time of the year, a large scale of high quality plantlets, ensuring varietal authenticity (Rout et al., 2006).

Efficiency of micropropagation involves an acclimatization step, which represents the transition 
from the heterotrophic to the autotrophic phase, when plantlets must increase photosynthetic rate and absorption of water and minerals (Grattapaglia \& Machado, 1998). Micropropagation techniques produce plantlets without pathogens, but eliminate arbuscular mycorrhizal fungi (AMF), which could bring great benefits to the hosts, whether in the production of seedlings in nurseries or in the acclimatization of micropropagated plants (Kapoor et al., 2008). Mycorrhization expands the absorption zone around the root, increasing the contact surface with the soil and favoring an increased uptake of minerals, such as phosphorus, zinc, copper, nitrogen, and potassium, resulting in increased plant tolerance to environmental stresses (Smith \& Read, 2008).

Although plant-fungus association is not specific, the natural occurrence of mycorrhizal associations in representatives of the family Costaceae has been documented (Santos et al., 2000). Specific favorable combinations between AMF and ornamental plant genotypes have been observed in anthurium (Anthurium andraeanum Lindl.) (Stancato \& Silveira, 2006), chrysanthemum (Chrysanthemum morifolium Ramat.) (Sohn et al., 2003), and gerbera daisy (Gerbera sp.) (Sato et al., 1999). However, lack of plant growth promotion has also been reported in associations of AMF with heliconia (Heliconia sp.) (Sato et al., 1999), red ginger [Alpinia purpurata (Vieill.) K. Shum.], and beehive ginger (Zingiber spectabile Griff.) (Silva et al., 2006). Therefore, the selection of mycorrhizal inocula that are effective in plantlet acclimatization and development is desirable for the improvement of propagation technology.

The objective of this work was to assess the potential of three AMF species to promote growth of micropropagated plantlets of $T$. ananassae during acclimatization.

\section{Materials and Methods}

The experiment was carried out in greenhouse, under controlled environmental conditions $\left(27 \pm 2^{\circ} \mathrm{C} ; 75 \%\right.$ relative humidity; light intensity of

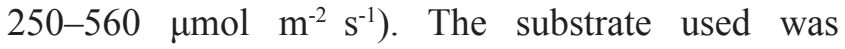
soil (Oxisol) and expanded vermiculite $\left(2: 1 \mathrm{v} \mathrm{v}^{-1}\right)$, previously sterilized in autoclave for two periods of 1 hour at $120^{\circ} \mathrm{C}$. The substrate had the following characteristics: $6.41 \mathrm{~g} \mathrm{~kg}^{-1}$ of organic matter, $\mathrm{pH} 5.6$, electrical conductivity of $0.54 \mathrm{dS} \mathrm{m}^{-1}$, cation-exchange capacity of $5.69 \mathrm{cmol}_{\mathrm{c}} \mathrm{dm}^{-3}, 93 \mathrm{~g} \mathrm{~kg}^{-1}$ of $\mathrm{P}, 0.44 \mathrm{~g} \mathrm{~kg}^{-1}$ of $\mathrm{K}, 1.5 \mathrm{~g} \mathrm{~kg}^{-1}$ of Ca, $1.3 \mathrm{~g} \mathrm{~kg}^{-1}$ of Mg, $0.84 \mathrm{mg} \mathrm{kg}^{-1}$ of $\mathrm{Cu}$, $68.9 \mathrm{mg} \mathrm{kg}^{-1}$ of Fe, $34.8 \mathrm{mg} \mathrm{kg}^{-1}$ of Mn, $2.10 \mathrm{mg} \mathrm{kg}^{-1}$ of $\mathrm{Zn}$, and $0.14 \mathrm{mg} \mathrm{kg}^{-1}$ of $\mathrm{Na}$. The plantlets were irrigated with about $50 \mathrm{~mL}$ of distilled water, daily, without supplement of nutrient solution.

Micropropagated plantlets of T. ananassae, provided by the Laboratório de Biotecnologia of Embrapa Semiárido, Petrolina, PE, Brazil, were multiplied in MS medium (Murashige \& Skoog, 1962).

Isolates of the AMF Glomus etunicatum Becker \& Gerd., Acaulospora longula Spain \& Schenck, and Gigaspora albida Schenck \& Smith were propagated in greenhouse in pots containing previously disinfected sand:soil $\left(1: 1 \quad \mathrm{v}^{-1}\right)$, with sorghum [Sorghum bicolor (L.) Moench.] as host. The inoculum produced was evaluated for the number of glomerospores by wet sieving and decanting (Gerdemann \& Nicolson, 1963), followed by centrifugation in water and sucrose $\left(40 \% \mathrm{~W} \mathrm{~V}^{-1}\right)$ (Jenkins, 1964). Counting was done in channeled plates, using a stereomicroscope (40×). After counting the glomerospores, soil inoculum was prepared to contain approximately 200 glomerospores, in addition to fragments of mycorrhizal-colonized root and mycelium.

The following treatments were established: non-inoculated control, and plants inoculated with G. etunicatum, A. longula, and G. albida. A completely randomized block design with ten replicates was used.

The micropropagated plantlets of $T$. ananassae were removed from growth flasks and washed in running water until the culture medium was completely removed. Specimens were selected in order to achieve uniformity of size and number of leaves and roots. At the moment of transplanting to $2-\mathrm{kg}$ bags containing substrate (soil and vermiculite, 2:1 v v ${ }^{-1}$ ), plantlets were inoculated or not, according to the treatment. In the control treatment, $2 \mathrm{~mL}$ of filtrate were added, which derived from the screening $(45 \mu \mathrm{m})$ of all inoculum tested, in order to standardize microbiota.

During the 90 days of acclimatization, height and number of leaves and tillers were assessed. At the end of the experiment, survival rates, leaf area, fresh and dry biomass of shoot and root, root colonization, number of glomerospores, and mineral contents in shoots and roots were determined.

To determine dry biomass, T. ananassae leaf and root were placed in oven $\left(65^{\circ} \mathrm{C}\right)$, until constant weight. After weighing, shoot samples were ground in a Wiley mill, 
in which 0.5 -g portions of sample were mineralized by nitric perchloric acid digestion for subsequent determination of $\mathrm{Ca}, \mathrm{Mg}, \mathrm{Fe}, \mathrm{Zn}, \mathrm{Cu}$, and $\mathrm{Mn}$ levels by atomic absorption spectrophotometry. Phosphorus was determined by colorimetry; and $\mathrm{K}$ by flame emission photometry. All tests were performed according to Silva (1999), and the values obtained were multiplied by dry biomass to determine mineral content.

Roots $(0,5 \mathrm{~g})$ from each treatment were washed in tap water, followed by clearing in $10 \% \mathrm{KOH}$ and $10 \% \mathrm{H}_{2} \mathrm{O}_{2}$, acidification in $1 \% \mathrm{HCl}$, and staining with trypan blue $(0.05 \%)$ (Phillips \& Hayman, 1970). Then, AMF colonization was estimated by the gridline-intersect method (Giovannetti \& Mosse, 1980). The number of glomerospores was determined by counting (Gerdemann \& Nicolson, 1963; Jenkins, 1964) in $50 \mathrm{~g}$ of soil of each treatment, and leaf area was estimated using the metering device Li 3100 (LI-Cor Inc., Lincoln, NE, USA). In order to determine the increment resulting from the treatments, the following formula was used: $\mathrm{I}(\%)=\left[(\mathrm{Tr}-\mathrm{T}) \mathrm{T}^{-1}\right] \times$ 100 , in which: I (\%) is the increment of the variable; $\mathrm{Tr}$ is the average value for the inoculated treatment; $\mathrm{T}$ is the average value for the non-inoculated treatment.

Data were subjected to analysis of variance and variables that showed significant difference were compared by the Tukey test, at 5\% probability, using Sanest software (Zonta \& Machado, 2007).

\section{Results and Discussion}

Plants colonized by $G$. etunicatum and A. longula showed a considerable increase in leaf area (Table 1): 175.67 and $95.12 \%$, respectively. In addition, inoculation with $G$. etunicatum had the best results for all biomass variables of $T$. ananassae, which that exceeded $100 \%$ (Table 1). The treatment with A. longula provided significantly higher biomass than control. Inoculation benefits with G. etunicatum and
Acaulospora sp. in acclimatization have also been reported for micropropagated gerbera (Sato et al., 1999) and anthurium plants (Stancato \& Silveira, 2006), and for chrysanthemum plants inoculated with different species of Glomus (Sohn et al., 2003).

Despite the high mycorrhizal colonization achieved with G. albida, inoculation with this AMF did not result in growth benefits or increase survival of $T$. ananassae plantlets (Tables 1 and 2). The values obtained were significantly similar to the control. According to Piotrowski et al. (2004), the lack of growth increment in root biomass may be related to excessive carbon sink for the formation of hyphae of some species of AMF with high colonization. This may be the case for members of the family Gigasporaceae, which were characterized by Hart \& Reader (2002) as producing larger amounts of extra-radicular mycelium, in comparison to other representatives of families of AMF. Moreover, the number of recovered glomerospores in the other treatments was significantly higher than that obtained with G. albida. A possible explanation is that the substrate used had a high phosphorus concentration $\left(93 \mathrm{~g} \mathrm{~kg}^{-1}\right)$, which may have directly influenced the functionality of the symbiosis (Siqueira et al., 2004), germination, and subsequent colonization (Lovelock \& Ewel, 2005).

After 45 days of evaluation, plantlets inoculated with $G$. etunicatum differed from the other treatments regarding height and number of leaves (Table 2), but not number of tillers, which differed significantly from the non-mycorrhizal plantlets after 75 days. More advanced stages of the plant-fungus relationship may allow the visualization of greater benefits for the host (Van der Heijden \& Kuyper, 2001). However, until the last day of evaluation (90 days), only inoculation with $G$. etunicatum and A. longula resulted in a significant increase in plant height, when compared to the control.

The content of macro- and micronutrients (Tables 3 and 4) in shoots and roots of plantlets inoculated

Table 1. Leaf area, mycorrhizal colonization, number of glomerospores, and fresh and dry biomass (g) of Tapeinochilos ananassae shoots and roots, in plants with or without mycorrhizal associations, after 90 days in greenhouse ${ }^{(1)}$.

\begin{tabular}{|c|c|c|c|c|c|c|c|c|}
\hline \multirow[t]{2}{*}{ Treatment } & \multirow[t]{2}{*}{ Survival } & \multirow{2}{*}{$\begin{array}{l}\text { Colonization } \\
\text { o) --------- }\end{array}$} & \multirow{2}{*}{$\begin{array}{l}\text { Leaf area } \\
\left(\mathrm{cm}^{2}\right)\end{array}$} & \multirow{2}{*}{$\begin{array}{c}\text { Number of merospores } \\
\left.\text { (50 } \mathrm{g}^{-1} \text { substrate }\right)\end{array}$} & \multicolumn{2}{|c|}{ Fresh } & \multicolumn{2}{|c|}{ Dry } \\
\hline & & & & & Shoot & Root & Shoot & Root \\
\hline Control & 100 & $0.03 \mathrm{~d}$ & $186.48 \mathrm{c}$ & $0.01 \mathrm{c}$ & $9.68 \mathrm{c}$ & $7.37 \mathrm{bc}$ & $0.97 \mathrm{bc}$ & $1.25 \mathrm{bc}$ \\
\hline Glomus etunicatum & 100 & $93.74 b$ & $514.07 \mathrm{a}$ & $23.90 \mathrm{a}$ & $26.78 \mathrm{a}$ & $21.26 \mathrm{a}$ & $2.96 \mathrm{a}$ & $3.69 \mathrm{a}$ \\
\hline Acaulospora longula & 100 & $81.45 \mathrm{c}$ & $363.87 \mathrm{~b}$ & $16.38 \mathrm{~b}$ & $18.55 b$ & $11.12 \mathrm{~b}$ & $1.45 b$ & $1.92 \mathrm{~b}$ \\
\hline Gigaspora albida & 80 & $99.12 \mathrm{a}$ & $189.53 \mathrm{c}$ & $1.00 \mathrm{c}$ & $9.41 \mathrm{c}$ & $5.62 \mathrm{c}$ & $0.81 \mathrm{c}$ & $0.83 \mathrm{c}$ \\
\hline $\mathrm{CV}(\%)$ & & 10.9 & 21.2 & 19.9 & 21.6 & 25.8 & 23.4 & 27.1 \\
\hline
\end{tabular}

${ }^{(1)}$ Means followed by equal letters do not differ by Tukey test, at $5 \%$ probability. 
Table 2. Height and number of leaves and tillers of Tapeinochilos ananassae with or without mycorrhizal associations with Glomus etunicatum, Acaulospora longula or Gigaspora albida, after 15, 30, 45, 60, 75, and 90 days in greenhouse ${ }^{(1)}$.

\begin{tabular}{|c|c|c|c|c|c|c|}
\hline \multirow[t]{2}{*}{ Treatment } & \multicolumn{6}{|c|}{ Time (days) } \\
\hline & 15 & 30 & 45 & 60 & 75 & 90 \\
\hline & \multicolumn{6}{|c|}{ Height $(\mathrm{cm})$} \\
\hline Control & $3.56 \mathrm{a}$ & $3.75 \mathrm{ab}$ & $3.62 b$ & $5.18 \mathrm{~b}$ & $5.31 \mathrm{~b}$ & $6.06 \mathrm{c}$ \\
\hline Glomus etunicatum & $3.62 \mathrm{a}$ & $4.43 \mathrm{a}$ & $5.87 \mathrm{a}$ & $9.62 \mathrm{a}$ & $12.31 \mathrm{a}$ & $15.68 \mathrm{a}$ \\
\hline Acaulospora longula & $3.25 \mathrm{a}$ & $3.31 \mathrm{~b}$ & $3.81 \mathrm{~b}$ & $4.81 \mathrm{~b}$ & $6.06 \mathrm{~b}$ & $9.18 \mathrm{~b}$ \\
\hline Gigaspora albida & $3.43 \mathrm{a}$ & $3.86 \mathrm{ab}$ & $4.43 \mathrm{~b}$ & $4.86 \mathrm{~b}$ & $5.00 \mathrm{~b}$ & $5.78 \mathrm{c}$ \\
\hline \multirow[t]{2}{*}{$\mathrm{CV}(\%)$} & 17.4 & 17.7 & 18.0 & 18.1 & 16.2 & 16.6 \\
\hline & \multicolumn{6}{|c|}{ Number of leaves } \\
\hline Control & $4.37 \mathrm{a}$ & $6.17 \mathrm{ab}$ & $7.25 \mathrm{~b}$ & $9.94 b$ & $12.50 \mathrm{~b}$ & $15.20 \mathrm{~b}$ \\
\hline Glomus etunicatum & $4.62 \mathrm{a}$ & $6.77 \mathrm{a}$ & $11.75 \mathrm{a}$ & $18.00 \mathrm{a}$ & $22.37 \mathrm{a}$ & $27.20 \mathrm{a}$ \\
\hline Acaulospora longula & $5.12 \mathrm{a}$ & $5.68 \mathrm{ab}$ & $5.00 \mathrm{~b}$ & $9.76 \mathrm{~b}$ & $14.62 b$ & 19.71ab \\
\hline Gigaspora albida & $4.50 \mathrm{a}$ & $4.64 \mathrm{~b}$ & $8.87 \mathrm{~b}$ & $7.98 \mathrm{~b}$ & $10.62 b$ & $15.11 \mathrm{~b}$ \\
\hline \multirow[t]{2}{*}{ CV $(\%)$} & 27.1 & 11.7 & 26.2 & 14.1 & 24.4 & 12.8 \\
\hline & \multicolumn{6}{|c|}{ Number of tillers } \\
\hline Control & $1.00 \mathrm{a}$ & $1.11 \mathrm{a}$ & $1.37 \mathrm{~b}$ & $2.03 \mathrm{a}$ & $2.25 \mathrm{~b}$ & $2.82 \mathrm{~b}$ \\
\hline Glomus etunicatum & $1.10 \mathrm{a}$ & $1.22 \mathrm{a}$ & $2.37 \mathrm{a}$ & $3.28 \mathrm{a}$ & $3.62 \mathrm{a}$ & $4.57 \mathrm{a}$ \\
\hline Acaulospora longula & $1.20 \mathrm{a}$ & $1.22 \mathrm{a}$ & $1.50 \mathrm{ab}$ & $2.06 \mathrm{a}$ & $2.50 \mathrm{ab}$ & $3.86 \mathrm{bc}$ \\
\hline Gigaspora albida & $1.10 \mathrm{a}$ & $1.11 \mathrm{a}$ & $1.50 \mathrm{ab}$ & $2.04 \mathrm{a}$ & $2.00 \mathrm{~b}$ & $3.44 \mathrm{ab}$ \\
\hline CV $(\%)$ & 27.9 & 11.3 & 38.3 & 17.9 & 32.0 & 13.9 \\
\hline
\end{tabular}

(1) Means followed by equal letters, in the columns, do not differ by Tukey test, at $5 \%$ probability.

Table 3. Macronutrient content (g per plant) of Tapeinochilos ananassae with or without mycorrhizal associations with Glomus etunicatum, Acaulospora longula or Gigaspora albida, 90 days after transplantation ${ }^{(1)}$.

\begin{tabular}{|c|c|c|c|c|c|c|}
\hline Treatment & $\mathrm{N}$ & $\mathrm{P}$ & $\mathrm{K}$ & $\mathrm{Ca}$ & $\mathrm{Mg}$ & $\mathrm{S}$ \\
\hline & \multicolumn{6}{|c|}{ Shoots } \\
\hline Control & $18.77 \mathrm{~b}$ & $0.77 \mathrm{~d}$ & $30.24 \mathrm{c}$ & $6.29 \mathrm{c}$ & $3.43 \mathrm{c}$ & $1.58 \mathrm{c}$ \\
\hline Glomus etunicatum & $36.81 \mathrm{a}$ & $4.41 \mathrm{a}$ & $81.11 \mathrm{a}$ & $18.61 \mathrm{a}$ & $18.18 \mathrm{a}$ & $6.55 \mathrm{a}$ \\
\hline Acaulospora longula & $31.94 \mathrm{a}$ & $2.62 b$ & $63.57 \mathrm{~b}$ & $11.34 \mathrm{~b}$ & $9.31 \mathrm{~b}$ & $3.91 \mathrm{~b}$ \\
\hline Gigaspora albida & $19.76 \mathrm{~b}$ & $1.63 \mathrm{c}$ & $30.82 \mathrm{c}$ & $7.54 \mathrm{c}$ & $5.37 \mathrm{c}$ & $1.83 \mathrm{c}$ \\
\hline \multirow[t]{2}{*}{$\mathrm{CV}(\%)$} & 20.5 & 13.3 & 19.6 & 19.0 & 17.8 & 17.4 \\
\hline & \multicolumn{6}{|c|}{ Roots } \\
\hline Control & $6.40 \mathrm{c}$ & $0.20 \mathrm{~b}$ & $14.49 \mathrm{c}$ & $3.05 \mathrm{~b}$ & $28.11 \mathrm{bc}$ & $1.36 \mathrm{c}$ \\
\hline Glomus etunicatum & $15.79 \mathrm{a}$ & $1.18 \mathrm{a}$ & $71.54 \mathrm{a}$ & $11.00 \mathrm{a}$ & $85.00 \mathrm{a}$ & $5.39 \mathrm{a}$ \\
\hline Acaulospora longula & $9.93 \mathrm{bc}$ & $1.00 \mathrm{a}$ & $30.48 \mathrm{~b}$ & $4.41 \mathrm{~b}$ & $34.50 \mathrm{~b}$ & $2.85 b$ \\
\hline Gigaspora albida & $11.71 \mathrm{ab}$ & $0.79 \mathrm{~b}$ & $20.35 \mathrm{bc}$ & $3.93 b$ & $21.23 \mathrm{c}$ & $1.52 \mathrm{c}$ \\
\hline CV $(\%)$ & 25.2 & 31.0 & 19.0 & 23.9 & 18.7 & 27.8 \\
\hline
\end{tabular}

${ }^{(1)}$ Means followed by equal letters do not differ by Tukey test, at $5 \%$ probability.

Table 4. Micronutrient content (mg per plant) of Tapeinochilos ananassae with or without mycorrhizal associations with Glomus etunicatum, Acaulospora longula or Gigaspora albida, 90 days after transplantation ${ }^{(1)}$.

\begin{tabular}{|c|c|c|c|c|c|c|}
\hline Treatment & $\mathrm{B}$ & $\mathrm{Cu}$ & $\mathrm{Fe}$ & $\mathrm{Mn}$ & $\mathrm{Zn}$ & $\mathrm{Na}$ \\
\hline & \multicolumn{6}{|c|}{ Shoots } \\
\hline Control & $46.28 \mathrm{c}$ & $11.82 b$ & $238.47 \mathrm{c}$ & $1191.19 \mathrm{c}$ & $60.43 \mathrm{c}$ & $652.27 \mathrm{c}$ \\
\hline Glomus etunicatum & $108.05 \mathrm{a}$ & $41.42 \mathrm{a}$ & $1032.83 a$ & $5009.90 \mathrm{a}$ & $252.06 \mathrm{a}$ & $1841.59 \mathrm{a}$ \\
\hline Acaulospora longula & $75.70 \mathrm{~b}$ & $34.46 \mathrm{a}$ & $554.48 \mathrm{~b}$ & $1740.40 \mathrm{~b}$ & $153.48 \mathrm{~b}$ & $1321.25 b$ \\
\hline Gigaspora albida & $66.92 \mathrm{bc}$ & $13.92 b$ & $321.18 b c$ & $436.29 \mathrm{~d}$ & $77.10 \mathrm{c}$ & $1074.20 \mathrm{bc}$ \\
\hline \multirow[t]{2}{*}{ CV (\%) } & 21.0 & 17.1 & 27.4 & 15.5 & 18.5 & 25.8 \\
\hline & \multicolumn{6}{|c|}{ Roots } \\
\hline Control & $32.77 \mathrm{c}$ & $37.34 \mathrm{bc}$ & $31027.50 \mathrm{c}$ & $536.07 \mathrm{bc}$ & $81.85 \mathrm{c}$ & $709.05 \mathrm{c}$ \\
\hline Glomus etunicatum & $134.83 \mathrm{a}$ & $116.27 \mathrm{a}$ & $96232.33 \mathrm{a}$ & $1949.04 \mathrm{a}$ & $365.12 \mathrm{a}$ & $3957.13 \mathrm{a}$ \\
\hline Acaulospora longula & $67.63 b$ & $50.84 \mathrm{~b}$ & $57454.66 b$ & $675.03 b$ & $159.97 b$ & $1542.38 \mathrm{~b}$ \\
\hline Gigaspora albida & $50.01 \mathrm{bc}$ & $27.33 \mathrm{c}$ & $27244.16 \mathrm{c}$ & $372.21 \mathrm{c}$ & $109.34 \mathrm{bc}$ & $1108.68 \mathrm{bc}$ \\
\hline CV (\%) & 28.4 & 23.4 & 23.0 & 17.2 & 18.4 & 22.7 \\
\hline
\end{tabular}

${ }^{(1)}$ Means followed by equal letters do not differ by Tukey test, at $5 \%$ probability. 
with $G$. etunicatum and A. longula, in general, was significantly greater than that of the control and G. albida. Similarly, Sohn et al. (2003) observed increased concentrations of $\mathrm{P}, \mathrm{K}, \mathrm{Mg}, \mathrm{Ca}, \mathrm{Fe}, \mathrm{Mn}$ and $\mathrm{Cu}$ in leaves and $\mathrm{K}, \mathrm{Ca}, \mathrm{Fe}, \mathrm{Mn}, \mathrm{Cu}$ and $\mathrm{Zn}$ in roots of chrysanthemum seedlings associated with Glomus sp. Using G. clarum, Leal et al. (2005) observed differential accumulation of $\mathrm{N}, \mathrm{P}$, and $\mathrm{K}$ in micropropagated banana plantlets. These results may be related to the compatibility between host and environment (Cavagnaro et al., 2005) or to the preferential association of certain combinations of plant genotype $\mathrm{x}$ species of AMF (Sanders, 2004), since not all isolates equally promoted the content of mineral nutrients (Table 3). Although mycorrhization with G. etunicatum has favored mineral accumulation in $T$. ananassae, this same strain reduced the concentration of some macronutrients, in spite of favoring the development of micropropagated banana plantlets (Yano-Melo et al., 1999).

Mycorrhization by A. longula provided aerial shoots of $T$. ananassae with greater accumulation of all macroand micronutrients, in comparison to the control. In the roots, the nutrient content in mycorrhizal plantlets showed significant difference only when compared to the control, regarding the macronutrients $\mathrm{P}, \mathrm{K}$, and $\mathrm{S}$ (Table 3) and the micronutrients $\mathrm{B}, \mathrm{Fe}, \mathrm{Zn}$, and $\mathrm{Na}$ (Table 4). The use G. albida inoculum did not increase the content of macro- and micronutrients, except for $\mathrm{P}$ in the shoot and $\mathrm{N}$ in the root portion, in comparison to the control (Table 3). Freitas et al. (2006) also observed that, in the absence of phosphate fertilizer in mint (Mentha arvensis L.), the use of G. margarita inoculum was responsible for the increased content of $\mathrm{N}, \mathrm{P}$, and K. However, inoculations with G. margarita also caused low levels of $\mathrm{Ca}$ and $\mathrm{Mg}$ in rootstocks of avocado (Persea sp.) (Silveira et al., 2002). Therefore, the nutritional benefits induced by AMF depend on the relative availability of elements in the environment (Siqueira et al., 2002). In addition, the evaluation of different isolates under the same conditions can assist in selection of more efficient AMF (Avio et al., 2006).

\section{Conclusions}

1. The isolate Glomus etunicatum has higher potential for application in Tapeinochilos ananassae acclimatization, with improved survival, plant growth, vigor and contents of mineral nutrients, besides promoting high fungal colonization and sporulation.
2. The inoculum of Acaulospora longula increase leaf area, biomass measures, and the concentration of macro- and microminerals in shoots and roots.

3. Inoculation with Gigaspora albida does not improve the contents of mineral nutrients and may even hamper the development of $T$. ananassae.

\section{Acknowledgements}

To Coordenação de Aperfeiçoamento de Pessoal de Nível Superior, to Conselho Nacional de Desenvolvimento Científico e Tecnológico, and to Fundação de Amparo à Ciência e Tecnologia do Estado de Pernambuco, for financial support; and to the staff of the biotechnology laboratory of Embrapa Semiárido, for support in the execution of the experiments.

\section{References}

AVIO, L.; PELLEGRINO, E.; BONARI, E.; GIOVANNETTI, M. Functional diversity of arbuscular mycorrhizal fungal isolates in relation to extraradical mycelial networks. New Phytologist, v.172, p.347-357, 2006.

CANÇADO JÚNIOR, F.L.; PAIVA, B.M. de; ESTANISLAU, M.L.L. Perspectivas para exportação de flores e plantas ornamentais. Informe Agropecuário, v.26, p.96-102, 2005.

CAVAGNARO, T.R.; SMITH, F.A.; SMITH, S.E.; JAKOBSEN I. Functional diversity in arbuscular mycorrhizas: exploitation of soil patches with different phosphate enrichment differs among fungal species. Plant Cell and Environment, v.28, p.642-65, 2005.

FREITAS, M.S.M.; MARTINS, M.A.; CARVALHO, A.J.C. Crescimento e composição da menta em resposta à inoculação com fungos micorrízicos arbusculares e adubação fosfatada. Horticultura Brasileira, v.24, p.11-16, 2006.

GERDEMANN, J.W.; NICOLSON, T.H. Spores of mycorrhizal Endogone species extracted from soil by wet sieving and decanting. Transactions of the British Mycological Society, v.46, p.235-244, 1963.

GIOVANNETTI, M.; MOSSE, B. An evaluation of techniques for measuring vesicular arbuscular mycorrhizal infection in roots. New Phytologist, v.84, p.489-500, 1980.

GRATTAPAGLIA, D.; MACHADO, M.A. Micropropagação. In: TORRES, A.C.; CALDAS, L.S.; BUSO, J.A. (Ed.). Cultura de tecidos e transformação genética de plantas. Brasília: Embrapa-SPI, 1998. p.183-260.

HART, M.M.; READER, R.J. Does percent root length colonization and soil hyphal length reflect the extent of colonization for all AMF? Mycorrhiza, v.12, p.297-301, 2002.

JENKINS, W.R. A rapid centrifugal-flotation technique for separating nematodes from soil. Plant Disease Report, v.48, p.692, 1964. 
KAPOOR, R.; SHARMA, D.; BHATNAGAR, A.K. Arbuscular mycorrhizae in micropropagation systems and their potential applications. Scientia Horticulturae, v.116, p.227-239, 2008.

LEAL, P.L.; MARTINS, M.A.; RODRIGUES, L.A.; SCHIAVO, J.A. Crescimento de mudas micropropagadas de bananeira micorrizadas em diferentes recipientes. Revista Brasileira de Fruticultura, v.27, p.84-87, 2005.

LOVELOCK, C.E.; EWEL, J.J. Links between tree species, symbiotic fungal diversity and ecosystem functioning in simplified tropical ecosystems. New Phytologist, v.167, p.219-228, 2005.

MURASHIGE, T.; SKOOG, F. A revised medium for rapid growth and bioassays with tobacco tissue cultures. Physiologia Plantarum, v.15, p.473-497, 1962.

PASQUAL, M.; SANTOS, F.C.; FIGUEIREDO, M.A. de; JUNQUEIRA, K.P.; REZENDE, J.C. de; FERREIRA, E.A. Micropropagação do abacaxizeiro ornamental. Horticultura Brasileira, v.26, p.45-49, 2008.

PHILLIPS, J.M.; HAYMAN, D.S. Improved procedures for clearing roots and staining parasitic and vesicular arbuscular mycorrhizal fungi for rapid assessment of infection. Transactions of the British Mycological Society, v.55, p.158-161, 1970.

PIOTROWSKI, J.S.; DENICH, T.; KLIRONOMOS, J.N.; GRAHAM, J.M.; RILLIG, M.C. The effects of arbuscular mycorrhizas on soil aggregation depend on the interaction between plant and fungal species. New Phytologist, v.164, p.365-373, 2004.

ROUT, G.R.; MOHAPATRA, A.; MOHAN JAIN, S. Tissue culture of ornamental pot plant: a critical review on present scenario and future prospects. Biotechnology Advances, v.24, p.531-560, 2006.

SANDERS, I.R. Intraspecific genetic variation in arbuscular mycorrhizal fungi and its consequences for molecular biology, ecology, and development of inoculum. Canadian Journal of Botany, v.82, p.1057-1062, 2004.

SANTOS, B.A.; SILVA, G.A.; MAIA, L.C.; ALVES, M.V. Mycorrhizae in Monocotyledonae of Northeast Brazil: subclasses Alismatidae, Arecidae and Zingiberidae. Mycorrhiza, v.10, p.151-153, 2000.

SATO, A.Y.; NANNETTI, D.C.; PINTO, J.E.B.P.; SIQUEIRA, J.O.; BLANK, M.F.A. Fungos micorrízicos-arbusculares no desenvolvimento de mudas de helicônia e gérbera micropropagadas. Horticultura Brasileira, v.17, p.25-28, 1999.
SILVA, F.C. da. Manual de análises químicas de solos, plantas e fertilizantes. Brasília, DF: Embrapa Comunicação para Transferência de Tecnologia, 1999. 370p.

SILVA, M.A. da; SILVA, F.S.B. da; YANO-MELO, A.M.; MELO, N.F. de; MAIA, L.C. Fungos micorrízicos arbusculares e vermicomposto na aclimatação de Alpinia purpurata (Viell.) Schum e Zingiber spectabile Griff. (Zingiberaceae). Acta Botânica Brasilica, v.20, p.249-256, 2006.

SILVEIRA, S.V. da; SOUZA, P.V.D. de; KOLLE, O.C. Influência de fungos micorrízicos arbusculares sobre o desenvolvimento vegetativo de porta-enxertos de abacateiro. Pesquisa Agropecuária Brasileira, v.37, p.303-309, 2002.

SIQUEIRA, J.O.; ANDRADE, A.T.; FAQUIM, V. O papel dos microrganismos na disponibilização e aquisição de fósforo pelas plantas. In: SIMPÓSIO SOBRE FÓSFORO NA AGRICULTURA BRASILEIRA, 2003, São Pedro. Fósforo na agricultura brasileira: anais. Piracicaba: Potafos, 2004. p.117-149.

SIQUEIRA, J.O.; LAMBAIS, M.R.; STÜRMER, S.L. Fungos micorrízicos arbusculares: características, associação simbiótica e aplicação na agricultura. Biotecnologia, Ciência e Desenvolvimento, v.25, p.12-21, 2002.

SMITH, S.E.; READ, D.J. Mycorrhizal symbiosis. $3^{\text {rd }}$ ed. San Diego: Academic, 2008. 769p.

SOHN, B.K.; KIM, K.Y.; CHUNG, S.J.; KIM, W.S.; PARK, S.M.; KANG, J.G.; RIM, Y.S.; CHO, J.S.; KIM, T.H.; LEE, J.H. Effect of the different timing of AMF inoculation on plant growth and flower quality of chrysanthemum. Scientia Horticulturae, v.98, p.173-183, 2003.

SPECHT, C.D.; STEVENSON, D.W. A new phylogeny-based generic classification of Costaceae (Zingiberales). Taxon, v.55, p.153-163, 2006.

STANCATO, G.C.; SILVEIRA, A.P.D. da. Associação de fungos micorrízicos arbusculares e cultivares micropropagadas de antúrio. Bragantia, v.65, p.511-516, 2006.

VAN DER HEIJDEN, E.W.; KUYPER, T.W. Does origin of mycorrhizal fungus or mycorrhizal plant influence effectiveness of the mycorrhizal symbiosis? Plant and Soil, v.230, p.161-174, 2001.

YANO-MELO, A.M.; SAGGIN-JÚNIOR, O.J.; LIMA-FILHO, J.M.; MELO, N.F.; MAIA, L.C. Effect of arbuscular mycorrhizal fungi on the acclimatization of micropropagated banana plantlets. Mycorrhiza, v.9, p.119-123, 1999.

ZONTA, E.P.; MACHADO, A.A. SANEST: sistema de análise estatística. Campinas: Instituto Agronômico, 2007.

Received on July 5, 2011 and accepted on August 10, 2011

Pesq. agropec. bras., Brasília, v.46, n.9, p.1099-1104, set. 2011 